\title{
The multiple facets of drug resistance: one history, different approaches
}

\author{
Evandro Luís Niero ${ }^{*}$, Bianca Rocha-Sales ${ }^{\dagger}$, Camila Lauand $^{\dagger}$, Beatriz Araujo Cortez ${ }^{\dagger}$, Marcelo Medina de Souza $^{\dagger}$, \\ Paula Rezende-Teixeira ${ }^{\dagger}$, Marcel Shiniti Urabayashi ${ }^{\dagger}$, Adam Arai Martens ${ }^{\dagger}$, Jorge Henrique Neves $^{\dagger}$ and \\ Gláucia Maria Machado-Santelli
}

\begin{abstract}
Some cancers like melanoma and pancreatic and ovarian cancers, for example, commonly display resistance to chemotherapy, and this is the major obstacle to a better prognosis of patients. Frequently, literature presents studies in monolayer cell cultures, 3D cell cultures or in vivo studies, but rarely the same work compares results of drug resistance in different models. Several of these works are presented in this review and show that usually cells in 3D culture are more resistant to drugs than monolayer cultured cells due to different mechanisms. Searching for new strategies to sensitize different tumors to chemotherapy, many methods have been studied to understand the mechanisms whereby cancer cells acquire drug resistance. These methods have been strongly advanced along the years and therapies using different drugs have been increasingly proposed to induce cell death in resistant cells of different cancers. Recently, cancer stem cells (CSCs) have been extensively studied because they would be the only cells capable of sustaining tumorigenesis. It is believed that the resistance of CSCs to currently used chemotherapeutics is a major contributing factor in cancer recurrence and later metastasis development. This review aims to appraise the experimental progress in the study of acquired drug resistance of cancer cells in different models as well as to understand the role of CSCS as the major contributing factor in cancer recurrence and metastasis development, describing how CSCs can be identified and isolated.
\end{abstract}

Keywords: Chemoresistance, Multidrug resistance, Cell death, 3D cell culture, Cancer stem cells

\section{Introduction}

The use of chemical agents to treat patients with cancer began with two studies in the 1940s. The synthesis and application of nitrogen mustard, a derivate compound from the chemical warfare agent mustard gas which, in addition to other damages, causes injury to blood cells and bone marrow degeneration. At the end of the same decade, observation of the relationship between folic acid and leukocyte proliferation and synthesis of compounds with antagonistic action to folic acid promoted a breakthrough in cancer treatment.

In 1942, Alfred Gilman and Louis Goodman treated a patient with advanced lymphosarcoma, which no longer responded to radiotherapy or surgery, with nitrogen

\footnotetext{
* Correspondence: eloniero@yahoo.com

${ }^{\dagger}$ Equal contributors

Department of Cell and Developmental Biology, Institute of Biomedical Sciences, University of São Paulo, Av. Prof. Lineu Prestes, 1524, Cidade Universitária, 05508-000 São Paulo, SP, Brazil
}

mustard. Halfway treatment they could perceive a symptomatic improvement and, at the end of the treatment period, biopsy revealed no tumor. However, the tumor reappeared weeks later and the treatment did not cause the same effect, with the patient's death weeks later [1]. In another clinical research, Sidney Farber introduced the administration of folic acid antagonists in patients with acute leukemia. The results showed that some compounds have the effect of temporarily inhibiting cell proliferation [2].

The results obtained in these two studies were similar in some aspects, such as the chemical agents being able to kill cancer cells, causing side effects and reappearance of tumors exhibiting resistance to the initial treatment. Subsequently to these events, other research groups sought to find substances that combined a more effective action on cancer cells and fewer side effects, as well as new strategies for drug administration [3-6]. 
Thus, drug resistance of cancer cells has been the subject of intense study. One of the first studies specifically investigating the resistance to folic acid antagonists was performed by Law [7]. Based on a study of bacterial resistance to a virus [8], the study of Law was conducted with the goal to find out the source of resistance of leukemic cells to folic acid antagonists, coming to the hypothesis that resistance seemed to arise from random mutations and selection.

The resistance of tumor cells to cytotoxic drugs is the major cause of failure of chemotherapy. This resistance, intrinsic or acquired, is a reflex of the result of numerous genetic and epigenetic alterations in cancer cells [9-11].

Anticancer drugs have targeted mainly the DNA, activating or silencing gene expression, and to do so drugs must penetrate an important cellular barrier, the plasma membrane. This should work as a line of defense and physical resistance to many classes of drugs $[12,13]$. Specific carriers actively transport some drugs through the membrane, and the resistance to them can be generated by reducing the drug carrier affinity or by decreasing the speed of transport. However, the efflux mechanism is assumed as the main responsible for the multiple drug resistance phenotypes.

This type of resistance involves the participation of the mechanisms of multidrug resistance (MDR), which include P-glycoprotein (P-gp), belonging to a family of ATP-dependent transporters. The intrinsic resistance is characterized by lack of sensitiveness to drug since the beginning of treatment, which is directly involved in the drug efflux [14].

Acquired resistance can develop by continuous exposure to drugs, which can trigger different cellular responses, such as blockage of apoptotic pathways, increased ability to repair DNA, changes in the control points of the cell cycle or induction of specific genes.

In the 40's, nitrogen mustard gas was used as a cytotoxic agent. Twenty years later, anticancer drugs derived from natural products (e.g. vinca alkaloids) have emerged, and these drugs were more harmful against tumor cells. Nevertheless, until the present days, the search for effective cancer therapies persists.

Nowell [15] proposed that the tumor develops from a single cell clone, which acquires selective advantage over the normal cell that gave rise to it. This hypothesis was supported by some evidence in common: biochemical or cytogenetic. Actually, in many primary tumors, cells exhibit the same abnormal karyotype. Nowell's proposal gave rise to what is known today as the clonal evolution model of a tumor cell population, in which natural selection in tumors leads to evolutionary changes and possibly drug resistance, ensuring the survival of cancer.
Another possibility for the development and maintenance of cancer arose when Lapidot et al. [16] and later Bonnet and Dick [17] found a subpopulation of cells in human chronic myeloid leukemia, which was capable of developing the disease in Severe Combined Immunodeficiency or Non-Obese Diabetic/Severe Combined Immunodeficiency mice (SCID or NOD/SCID). These cells showed a phenotype to surface receptors $\left(\mathrm{CD} 34^{+} / \mathrm{CD} 38^{-}\right)$ similar to hematopoietic progenitor cells and the same ability to self-renewal and differentiation, so they were termed as cancer stem cells (CSCs). It was also confirmed the presence of CSCs in several solid tumors (reviewed by Visvader and Lindeman [18]).

The purpose of this review is to report the main molecular mechanisms that lead to drug resistance. This article also aims to show some new methods used to study drug resistance in 2D and 3D cell cultures, as well as to understand the role of CSCs as the major contributing factor in cancer recurrence and later metastasis development, describing how CSCs can be identified and isolated.

\section{Review \\ Drug resistance}

Several mechanisms are associated with chemoresistance of tumor cells, but two of them have been extensively investigated along the years: apoptosis inhibition [11,19-21] and multidrug resistance, which is responsible for exporting cytostatic substances through the cell membrane [22-25].

\section{Multidrug resistance}

Various factors can contribute to chemoresistance in tumors, such as the cellular microenvironment and some molecules synthesized by these cells [23]. The ABC (ATP-binding cassette) protein superfamily plays an important role in the distribution of intrinsic and extrinsic (drugs, for example) molecules to the human organism. Internalization of these substrates (molecules, drugs) occurs by active transport. Their transport is dependent on the hydrolysis of ATP. Members of that superfamily of proteins are expressed in many tissues and their isoforms are widely studied. Among them we can mention the group of MDR proteins [26]. In 1987, researchers have shown that P-glycoprotein, one of the most important member of the ABC transporter superfamily, is also encoded in normal tissues; they used the monoclonal antibody MRK16 to determine the location of P-gp [27]. Cancer cells show different expression of MDR proteins and this is a huge contributor to chemoresistance in tumors [23].

The main form of drug resistance is the capacity of cells to express genes that encode membrane transport proteins [22] as P-gp, encoded by ABCB1 (MDR1) gene. The proteins that form the MDR system are able to alter 
the efflux and influx of many drugs, and so, change the cytotoxic effects of these drugs [23]. Many chemotherapeutic drugs, such as anthracyclines, are substrate for the MDR proteins, and this could impair the effectiveness of cancer treatment [28-30].

Aran et al. [24] observed that NIH3T3 (fibroblast of Mus musculus embryo) cells were positively influenced when treated with colchicine. Higher concentrations of colchicine increased the expression of the MDR1 gene that encodes P-glycoprotein, so an augment of the drug would be directly related to drug resistance.

Januchowski et al. [22] studied six ovarian cancer cell lines W1MR, W1CR, W1DR, W1VR, W1TR and W1PR (respectively resistant to methotrexate, cisplatin, doxorubicin, vincristine, topotecan and paclitaxel - that is the most commonly prescribed drug to the treatment of ovarian cancer). The W1 cell line was previously established by their group years before. It is important to note that the tissue was obtained from an untreated patient and the resistant cell lines were obtained by exposure of the W1 cell line to increasing concentrations of each drug. Their results showed high levels of P-gp protein expression in W1PR cell line, pronounced expression in W1DR and low levels in W1VR, compared to others cell lines that did not express P-gp, The results suggest that $\mathrm{P}$-gp is the responsible for chemoresistance in these cell lines. The authors also found a relation between the MRP2 transcript level and methotrexate resistance in the cell lines described above.

Usually, cancer treatment combines surgery and chemotherapy/radiotherapy in order to improve patient survival or eradicate the disease. Oosterwijk et al. [31] concluded that it is possible to sensitize chondrosarcoma established cell lines and primary cultures to doxorubicin and cisplatin by repairing the apoptotic machinery.

Although there are many drugs that can act on P-gp to circumvent drug resistance in chemotherapy, their effective action can be compromised due to the multiplicity of signal transduction pathways involved in P-gpmediated MDR, such as MAPK, JNK, PI3K, among others; as well as some transcription factors, like NF- $\mathrm{kB}$, TNF- $\alpha$, PTEN that could confer different levels of P-gp expression in different environments and conditions (reviewed in Sui et al. [32]).

Besides P-gp, another protein that is widely investigated is the MRP1 (multidrug resistance associated protein 1 ). This protein is greatly related to chemoresistance in different types of tumors, such as lung cancer, but its expression is a characteristic of childhood neuroblastoma [25].

Increased expression of MRP1 is strongly associated with the capacity of cancer cells to migrate and form a secondary tumor [33]. Other studies have shown that MCF-7 cell line cultured as spheroids exhibited an increased resistance to doxorubicin and cell-cell interactions could be significant modulators in the drug resistance inMCF-7 cell line and a resistant variant (MDR-MCF-7) [34]. These data indicate a link between MDR and tumor ability of invasiveness and metastasis.

Micro RNAs (miRNA), a family of small noncoding RNAs that regulate gene expression, can be involved in chemotherapy resistance through the regulation of MDR proteins at a post-transcriptional level. The interaction of miRNAs with the targeted mRNA can negatively modulate MDR proteins improving the tumor cell response to anticancer drugs. miRNAs are heavily explored because they represent an alternative for combined therapeutic of cancer. Yang et al. [35] described that miR-223 can downregulate ABCB1 and mRNA levels, suggesting that miR-223 plays an important role in the regulation of MDR proteins mediated by $\mathrm{ABCB} 1$ gene product in HCC cell lines.

The gene ABCC4 encodes the MRP4 protein, which is found in many tissues like renal tubules and blood cells and is another efflux membrane transporter. miR-124a and miR-506 significantly decreased MRP4 protein levels in HEK293T/17 (normal human embryonic kidney), however these miRNAs did not change the gene transcription levels [36]. MCF7 mitoxantone-resistant cells (MCF7/MX) derived from MCF7 cells, overexpress the breast cancer resistance protein (BCRP), encoded by the ABCBG2 gene, which is a target of miR-181a. The induction of miR-181a overexpression increased the sensitivity of both lines, MCF7 and MCF7/MX, to mitoxantone [37].

\section{Cell death and chemoresistance}

The drug-activated cell death pathway depends on the cell type. Thus, a chemotherapeutic substance may trigger a large variety of tumor responses according to the organ or tissue considered. Many of the signals that elicit apoptosis converge on the mitochondria, which respond to pro-apoptotic signals by releasing cytochrome c [38]. There are two great classes of chemotherapeutic drugs: molecules that induce cell death in interphase cells, frequently by causing DNA damage, like cisplatin $[39,40]$ (reviewed in Eckstein [41]), and others that induce cell death by mitosis blockage, usually by interfering in microtubules dynamic, like paclitaxel $[42,43]$.

p53 was the first described tumor suppressor gene associated with apoptosis and it has been extensively studied along the years, because mutations in this gene occur in the majority of human tumors. Furthermore, p53 mutations are frequently associated with advanced tumor stage and poor patient prognosis. However, p53 mutations alone are not the only responsible for tumor progression: several upstream and downstream molecules of the p53 pathway (MDM2, p19ARF and Bax) are 
usually altered in human tumors [44]. Nevertheless, studies have failed to correlate p53 mutations with reduced toxicity to anti-cancer agents in some tumors like melanoma [45].

Mutations can vary according to the tumor tissue, and different drugs must be tested to attack different types of cancers. 5-fluorouracil (5-FU), for example, is the most common antimetabolite used for the treatment of colorectal cancer. Researchers have demonstrated that 5-FU exerts its cytotoxicity through induction of apoptosis, but the drug is not completely effective because of an inducible chemoresistance mechanism. 5-FU induced the activation of NF- $\mathrm{kB}$ in two colon cancer cell lines [21] and four of five thymidylate synthase inhibitorresistant colon cancer cell lines were found to overexpress NF- $\mathrm{kB}[20]$.

$\mathrm{NF}-\mathrm{kB}$ is a family of ubiquitous transcription factors that includes p50/p105, p52/p100, RelA (p65), c-Rel, and RelB [46]. It is known that numerous proteins, including C-myc, Cyclin D1, Bcl-2, COX-2, Bcl-xL and Survivin, are all regulated by $\mathrm{NF}-\mathrm{kB}$ at the transcriptional level and linked to chemoresistance. [11,19,47-50] showed that transfection with adenovirus IkB $\alpha$ super-repressor strongly inhibited constitutive activation of $\mathrm{NF}-\mathrm{kB}$ and significantly enhanced 5-FU and 5-FU/Folinic acidmediated growth inhibition.

Many other studies have demonstrated a correlation between NF- $\mathrm{kB}$ and chemoresistance in different cancer cells. Chemoresistance in pancreatic cancer, for example, has been associated with activation of NF- $\kappa B$, and its inactivation leads to cell sensitization to conventional therapeutics [51-53]. Gemcitabine remains as the best treatment available for advanced pancreatic cancer, but this drug alone activates NF- $\mathrm{kB}$, decreasing the apoptosis rate in vitro $[54,55]$.

Wang et al. [55] showed that escin, a natural mixture of triterpene saponins, increased apoptosis rate in BxPC3 and PANC-1 cells by downregulating NF- $\mathrm{kB}$, and consequently C-myc, Cyclin D1, Bcl-2, COX-2, Bcl-xL and Survivin. They also showed that the combination of gemcitabine and escin was more effective. Xiao \& Wei [56] and Harikumar et al. [57] have already reported that escin could reduce the activity of NF-kB. Other works demonstrated that escin exhibited antitumor effects in various cancer cells [58-61] and enhanced the effects of paclitaxel and doxorubicin in human hepatocellular carcinoma cells.

A long-term treatment of cancer cells with a chemotherapeutic drug usually results in cells resistant to the treatment. Barr et al. [62] established cell lines resistant to cisplatin with increasing doses of the drug and demonstrated that these cells have increased NF- $\mathrm{kB}$ expression and stem cell-like signature. Treatment of resistant cells in murine models with genistein, an Akt/NF-kB inhibitor, sensitizes cells to cisplatin-induced cell death [63].

Evidences suggest that not only NF-kB, but also PI3K/ Akt signaling pathway, is associated with chemoresistance development in cancers (Figure 1). PI3K-Akt pathway is a known regulator of cell survival that controls pro-survival and antiapoptotic proteins such as Cyclin D1, Bcl-2, Bcl-xL and XIAP [64-67].

Many natural products that activate different stages of the cell death cascade are synergistic in combination with effective chemotherapeutic agents. For example, curcumin, the yellow pigment in Indian saffron, potentiates the antitumor activity of various chemotherapeutic agents, including paclitaxel, gemcitabine and cisplatin, in a wide range of cancer cells by suppressing the expression of important antiapoptotic proteins [68-70].

Natural products have been studied in different tumor models due to their effective potential against cancer cells and relatively low cytotoxicity in normal cells [71-73]. Actually, natural products could protect normal cells against pathological changes caused by drugs like doxorubicin [11].

Yang et al. [74] found that tectorigenin, a type of $\mathrm{O}$ methylated isoflavone, does not induce potent cell death alone, but significantly sensitizes human ovarian cancer cells to paclitaxel-induced cytotoxicity by inactivating the $\mathrm{Akt} / \mathrm{IKK} / \mathrm{I} \kappa \mathrm{B} / \mathrm{NF}-\kappa \mathrm{B}$ signaling pathway. Flavonoids like tangeretin and genistein showed important chemosensitization of drug-resistant ovarian cancer cells to different agents like cisplatin and taxane drugs, as well as gemcitabine and topotecan. These natural compounds increased cell death by downregulating the PI3K/Akt pathway [75].

PI3K/Akt is another important signaling pathway involved in acquired chemoresistance of many cancers. Akt is also known as protein kinase B (PKB). All of its isoforms (Akt1, Akt2 and Akt3) are phosphorylated (activated) by a phosphatidylinositol 3-kinase (PI3-K) in response to growth factors to promote cell survival [76]. Increased activation of different isoforms of Akt has been associated with different cancers [77-79].

A number of works demonstrated that the Akt pathway is directly related to resistance of cancers against different drugs like sorafenib, trastuzumab and erlotinib [80-82]. The epigenetic control of Akt and NF-kB is important for the establishment of drug resistance. Lin et al. [83] found that RUNX3 suppresses Akt1 transcription by directly binding to the Akt1 promoter. Zheng et al. [84] showed that methylation of RUNX3 induces activation of the Akt signaling pathway. This mechanism of control would be responsible for inducing docetaxel chemoresistance in human lung carcinoma and the treatment of docetaxelresistant lung cancer cells with a specific DNA methyltransferase inhibitor decreased the cell viability. 


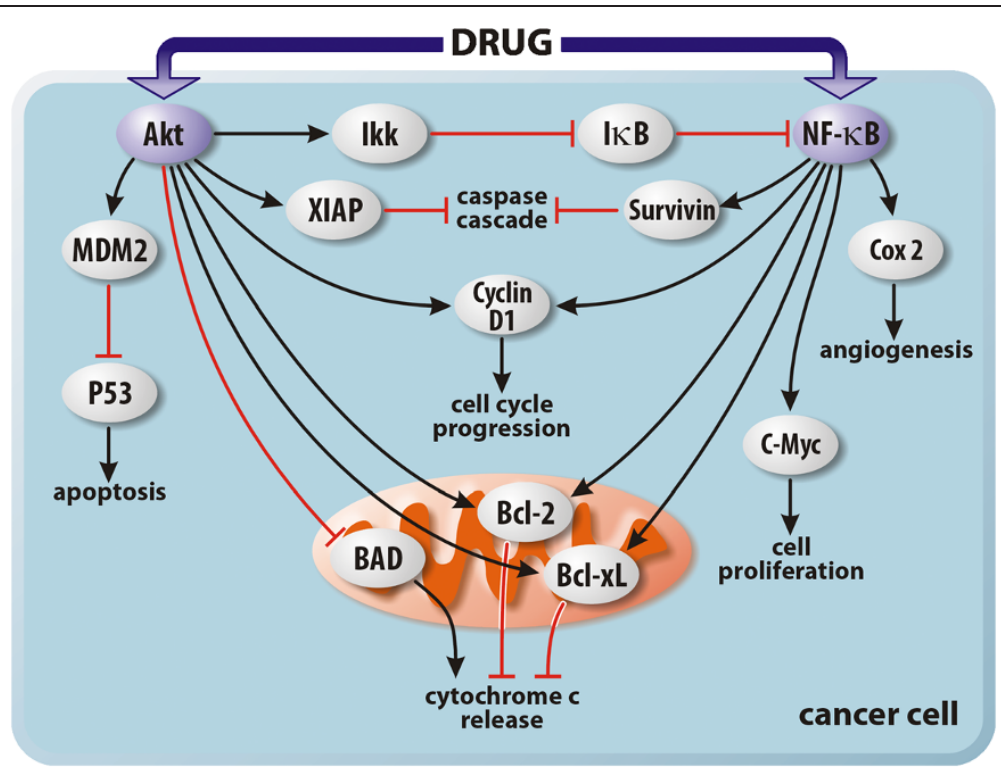

Figure 1 The role of Akt and NF-KB signaling in drug resistance mechanism of tumor cells. Several drugs induce the activation of Akt and NF-kB signaling pathways. Akt activation inhibits the P53 and BAD pathways leading to cell survival. Akt also stimulates Ikk, which inhibits 1 kB and triggers NF-KB signaling pathway. NF-KB activates C-Myc and COX 2 that are mainly involved in cell proliferation and angiogenesis, respectively. Both Akt and NF-KB activate the antiapoptotic proteins $\mathrm{BCl}-2$ and $\mathrm{BCl}-\mathrm{xL}$, inhibiting the Cytochrome-c release from mitochondria, and Cyclin D1, which contributes to cell cycle progression. Akt and NF-KB also inhibit the caspase cascade by XIAP and Survivin activation, respectively.

Different compounds have been used to target the Akt pathway. Liu et al. [85] induced apoptosis in gefitinibresistant lung cancer cells by using benzyl isothiocyanate, which suppressed the activity of Akt/MAPK pathways. Gao et al. [86] found that apigenin, a natural flavonoid, could be an adjuvant sensitizer in doxorubicin-resistant hepatocellular carcinoma, once this natural compound inhibited the PI3K/Akt/Nrf2 pathway in the resistant cells.

Anoikis is a type of programmed cell death that is induced by disruption of cell-matrix interactions in epithelial cells, named so by Frisch and Francis [87], although there are reports of the anchorage-dependent cell growth and viability dating back to the 1960's [88]. This process is an important step for maintaining the balance between cell proliferation and cell death in healthy tissues [89]. Basically, extracellular matrix (ECM) signaling and interactions with epithelial cells determine their correct location, preventing detached cells to colonize different tissues than their own. However, an important aspect of chemoresistance in cancer cells (especially in carcinomas) is resistance to anoikis, which can confer these cells the ability to detach from their original tissue and not only survive but also migrate to secondary sites and invade other tissues, i.e. metastasize [90].

Anoikis activation is associated with the inactivation of pro-survival genes after cytoskeleton rearrangement [91]. In cancer, pro-survival pathways, such as Akt and ERK pathways, are activated to suppress anoikis signaling. Researchers have implicated Akt pathway activation in anoikis suppression during resistance to chemotherapeutic agents as mitoxantrone, cisplatin and 5-FU, but no decreased sensitivity to paclitaxel [92]. In other study, overexpression of CEACAM6 (Carcinoembryonic Antigen-related Cell Adhesion Molecule 6) was associated with chemoresistance to gemcitabine in pancreatic adenocarcinoma [93]. However, Diaz-Monteiro and McIntyre [94] have found that anoikis resistance is not directly related to chemotherapy resistance in osteosarcoma, probably involving distinct activation steps.

Recently, works on miRNAs approached different aspects of anoikis resistance and chemoresistance, i.e., reducing mobility of anoikis-resistant cells as well as increasing their sensitivity to paclitaxel in endometrial and ovarian cancer cells [95]. Even though studies have managed to place intermediate proteins in signaling pathways leading to anoikis resistance, there are many different pathways that culminate in the evasion of anoikis. Hence, much is yet to be discovered to elucidate this process in cancer progression.

\section{Heat shock proteins in tumor resistance}

Other sensitizers that have been studied in potential combinational therapies are the heat shock proteins (HSPs). HSPs are chaperones with cytoprotective role into the cells responsible by proper folding of proteins. HSPs are classified according to their molecular weights in Hsp100, Hsp90, Hsp70, Hsp60, Hsp40 and small HSPs [96]. Among these proteins, Hsp90, 70, 40 and 27 
have received special attention in studies that aim to inhibit tumor growth and progression. Hsp70 and Hsp90 are proteins directly involved in refolding proteins; Hsp40 transfers the unfolded protein to Hsp70 by complexing with HIP (Hsp70 interacting protein) and stimulates the ATPase activity of Hsp70; Hsp27 prevents aggregation of unfolded proteins into the cytoplasm $[97,98]$.

Jeong et al. [99] demonstrated the association between Hsp90 inhibition and decrease in proliferation of a nonsmall cell lung cancer (NSCLC) cell line resistant to gefitinib. Other study using NSCLC cells showed that treatment with Hsp90 inhibitor ganetespib induced loss of EML4-ALK gene rearrangement found in this type of tumor and depletion of multiple oncogenic proteins [100]. Hsp90 inhibitor CH5164840 showed antitumor activity on NSCLC cell lines and enhanced the efficacy of erlotinib. The combination of these compounds suppressed ERK signaling in a cell line resistant to erlotinib [101]. Hsp90 inhibition lead to apoptosis induction by mitochondrial pathway in melanoma, cervix, colon, liver and lung cancer cells and induced apoptosis in cells overexpressing Bcl-2 [102].

Hsp70 is currently upregulated in several cancer types and can be induced by drugs that trigger the heatshock pathway signaling. Hsp70 protects normal and tumor cells from death by binding to Bax and Apaf-1 after a stress stimulus $[103,104]$. A barrier to the complete successful of Hsp90 inhibition in treatment of cancers is that its inhibition increases the Hsp70 expression [105]. Some authors showed that inhibition of Hsp70 alone is few less or ineffective to cause cell death in tumors, nevertheless it could enhance the antitumor effects of other drugs a great coadjuvant in the treatment of cancers [106-108]. The Hsp40 group has a role as cochaperone for Hsp70 and indirect regulator of Hsp90 and it contains the greatest number of members. In fact, the diversity of structures and functions of the group makes targeting Hsp40 very challenging (for review, see Sterrenberg et al. [109]).

Different works showed the relationship between Hsp27 and direct activation of Akt, increasing the cell survival signaling pathway by regulating negatively pro-apoptotic proteins in different models [110,111]. Kim et al. [112] demonstrated that inactivation of ERK/ p90RSK/HSP27 cascade in SK-OV-3 cells by melatonin enhances cisplatin-induced apoptosis. Hsp27 inhibition by quercetin also reduced the viability of A549 cells when used in combination with cisplatin or gemcitabine when compared to these drugs alone showing the role of Hsp27 in chemoresistance [113]. Other studies showed the antitumor effects of Hsp27 inhibition in combination with other drugs (for review, see McConnell \& McAlpine [114].

\section{Monolayer x 3D cell culture}

Cell culture in a monolayer system, also known as twodimensional culture (2D), does not maintain the same features found in vivo. The development of other culture systems are growing up to achieve one that better mimics the in vivo cellular features, very important to improve studies about cancer disease, for example, in the evaluation of drug effects in cancer cells [115]. The three-dimensional culture (3D) is a type of culture that increases cell interactions with other cells and with the ECM, which is closer to in vivo conditions [116,117].

The increased cell-cell or cell-matrix interactions observed in 3D culture can: a) augment cell differentiation [118-120]; b) change cell signaling in response to ECM compounds [121]; c) modify the gene expression pattern $[122,123]$; and d) alter the expression of proteins linked to cell adhesion to matrix (integrins) and cell-cell adhesion (cadherins) [124]. The expression of integrin and E-cadherin distribution in spheroids were similar to in vivo results $[125,126]$.

There are several models of cell culture in a $3 \mathrm{D}$ environment, such as: multicellular spheroids [127,128], microcarrier beads, synthetic (synthetic gels) or natural materials (matrigel, a gel with ECM obtained from mouse sarcoma cells in culture, and type I collagen) that provide cell growth in a three-dimensional system and organotypic explant culture [121].

The 3D culture may be a good model for both basic and applied research. Cancer cells culture in a 3D system is very interesting to study cancer disease, for example, evaluating the effects of drugs in these cells. Cells maintained in a 3D environment are organized in multiple layers that confer a biological barrier to drug diffusion, like small avascular tumor aggregates observed in vivo [121]. Fourré et al. [129] cultivated fibrosarcoma cells HT-1080 in a 3D culture type with type I collagen and showed that doxorubicin cell penetration took about 1 more hour compared to cells grown in a $2 \mathrm{D}$ system. Other works showed similar results with the same drug: Yip \& Cho [130] found that cells cultured in the presence of collagen hydrogel had higher cell viability and Millerot-Serrurot et al. [131] observed that ECM protected cancer cells from anti-migratory effect of doxorubicin. However, in these cases, the decreased drug penetration was due to mechanical resistance and not cell chemoresistance [132].

Some cell types become more resistant to cell death via apoptosis while they are in contact with other cells or with the ECM, as it occurs in 3D cell cultures. For example, cell adhesion mediated by integrins leads to increased expression of integrin receptors and fibronectin, such as VLA-4, which seems to be related to apoptosis resistance $[133,134]$. Also, in some 3D models in which cells became polarized after the contact with an ECM 
similar to the basement membrane, the expression of beta4 integrin was associated with resistance to apoptosis [135]. This type of resistance, also known as CAMDR (cell adhesion mediated drug resistance), is seen today as a target to anti-cancer therapies $[136,137]$.

Studies have shown that cells are more resistant to drugs when grown in 3D cultures than when they are in monolayer. Longati and co-workers [138] tested the resistance of pancreatic ductal adenocarcinoma cell line (PDAC) in 2D and 3D cultures. The cells are more resistant to gentamicin, CD5, CB7, CB13, Act16412 and GANT61 when they are in 3D cultures. Human ovary cancer cells (SKOV3 cells), when cultured in 3D to mimic ascites, form cell aggregates resistant to paclitaxel $[139,140]$. This resistance could be due to high expression levels of KLK4 (high tumor kallikrein-related peptidase 4) [140]. Similarly, stem cells isolated from SKVO3 cultures, when cultivated in a 3D environment with basement membrane extract scaffold, are resistant to docetaxol, cisplatin, carboplatin and 5FU. In cells grown in this model of $3 \mathrm{D}$ culture, the expression of $\mathrm{ABCB} 1$ and $\mathrm{ABCG} 2$ are increased and could be related to resistance to the drugs tested [141]. Lung cancer cells also become resistant to bortezomib when in 3D cultures [142], as well as MCF-7 cells which become resistant to 5 -FU in specific stages of spheroid formation [143].

Some genes related to drug resistance in 2D cultures are over expressed in 3D cultures and could be involved with drug resistance in these models. Among these genes, we can mention BCL-2 family members, ABCG2 and $\mathrm{ABCB} 1, \mathrm{CP} 78$ and KLK4. Other interesting hypothesis for drug resistance in $3 \mathrm{D}$ cultures is related to the increased cell adhesion and matrix elements synthesis in these models, making it difficult for drugs to penetrate in the spheroids and reach all the cells [138]. However, some studies show that certain drugs such as doxorubicin can penetrate in spheroids and be incorporated in cells nuclei within these large structures. In this case the drug retention does not depend on MDR1 bombs, but the resistance seems to be related to the expression of Bcl-2 family members [31].

Fourré and co-workers [129] also show in collagen rich models that doxorubicin and anthracyclins take more time to be detected in cell nuclei and that in these cases it takes longer treatments to reach similar cellular responses to those seen in $2 \mathrm{D}$ cultures.

Nirmalanandhan and co-workers [144] tested 10 different drugs in lung cancer (A549) and bronchioalveolar cancer (H358) cells cultured in 2D and 3D models with type I collagen. When tested in H358 cells, 8 of the 10 drugs needed different concentrations to reach the same effects in 2D and 3D. In A549 cells 7 of the 10 drugs showed similar effects but in different concentration.
The results depend on the cell line and on the drug class, and show that more studies should be done to determine if the mechanisms of chemoresistance in 3D models share the same features of the mechanisms observed in 2D cultures. Moreover, it is important to evaluate if the cell responses to drugs in $3 \mathrm{D}$ are more similar to what happens in vivo than those observed in $2 \mathrm{D}$ cultures, making it a new way to test drugs and to evaluate chemoresistance. A summary of studies with drug resistance in $2 \mathrm{D}$ and $3 \mathrm{D}$ cell cultures is presented in Table 1.

\section{Cancer stem cells}

The concept of cancer stem cell (CSC) was stated based on the organization of multicellular organisms presenting somatic stem cell populations that give rise to committed progenitors which are able to differentiate into mature cells. Normal cellular hierarchy comprises stem cells that progressively generate more restricted progenitor cells, yielding all the mature cell types that constitute a particular tissue. Cancer would simulate organ development, exhibiting a similar hierarchy with different cell populations, including the CSCs, associated to high drug resistance.

In the strict sense, CSCs and tumor initiating cells (TICs), i.e., cells that acquired the tumor promoting mutations are conceptually different. CSCs (and not other tumor cells) would be the only cells capable of sustaining tumorigenesis due to their self-renewal and asymmetric division abilities. TICs are defined as cells capable of initiating a tumor in immunocompromised mice [145]. However, the terms CSCs and TICs have being indistinctly used to refer to the small cellular subpopulation $(0.01-1 \%$ of total tumor cells) first described in leukemia and then in breast cancer and others solid tumors $[16,17,146,147]$. These cells are able to induce cancer when transplanted to immunodeficient mice, have drug resistance and self-renewal ability. It is believed that the resistance of CSCs to currently used chemotherapeutics is a major contributing factor in cancer recurrence and later metastasis development.

According to their phenotypes, CSCs can be identified and isolated by means of 4 main methodologies: a) cell sorting by flow cytometry using specific cell surface markers $[148,149]$; b) assessment of aldehyde dehydrogenase (ALDH) activity [150]; c) cell sorting of sidepopulation (SP) phenotype by Hoechst 33342 exclusion [151]; d) spheres isolation, since CSCs are able to form floating colonies from a single cell more efficiently than their progeny [152] and to grow as spheres in nonadherent culture conditions [153].

The most commonly used surface markers are CD44+ and CD133+ $[17,146]$. CSC phenotype in leukemia was associated with CD44+/CD38- cells [16]. CD44 is a 
Table 1 Effects of some drugs and cancer cell mechanisms of drug resistance in monolayer and in three-dimensional cell cultures

\begin{tabular}{|c|c|c|c|c|}
\hline Drug & Cell type & Effects in 2D and 3D cultures & Processes related to chemoresistance & Reference \\
\hline $\begin{array}{l}\text { Doxorubicin/ } \\
\text { Paclitaxel/ } \\
\text { Tamoxifen/ }\end{array}$ & MCF-7 (breast carcinoma) & $\begin{array}{l}\text { Antiproliferative effect increased in } \\
\text { 2D; cells more resistant to drugs in } \\
\text { 3D. }\end{array}$ & $\begin{array}{l}\text { Increased ECM production in 3D models, } \\
\text { difficulting drug diffusion. }\end{array}$ & $\begin{array}{l}\text { Horning } \\
\text { et al. [143] }\end{array}$ \\
\hline AG1478 & $\begin{array}{l}\text { SW-480, HT-29, DLD-1, LOVO, } \\
\text { CACO-2. COLO-205, COLO- } \\
\text { 206F (Colorectal Cancer Cell } \\
\text { Lines) }\end{array}$ & $\begin{array}{l}\text { Cell viability decreased in a dose- } \\
\text { dependent way in } 2 D \text { and 3D, but } \\
\text { more clearly in } 2 D \text {. }\end{array}$ & $\begin{array}{l}\text { Cells in 3D showed decreased expression of } \\
\text { EGFR. ECM signaling can be involved too. }\end{array}$ & $\begin{array}{l}\text { Luca et al. } \\
\quad[98]\end{array}$ \\
\hline $\begin{array}{l}\text { 5FU/ Docetaxel/ } \\
\text { Cisplatin/ } \\
\text { Carboplatin }\end{array}$ & $\begin{array}{l}\text { SKOV-3 cell line (epithelial } \\
\text { ovarian cancer). Stem cells } \\
\text { were selected from these } \\
\text { cultures. }\end{array}$ & $\begin{array}{l}\text { Antiproliferative effect increased in } \\
2 \mathrm{D} \text {. Cells in } 3 \mathrm{D} \text { models more } \\
\text { resistant to drugs. }\end{array}$ & $\begin{array}{l}\text { Decreased apoptotic induction in 3D. } \\
\text { Increased expression of } A B C G 2 \text { e ABCB1 in 3D. }\end{array}$ & $\begin{array}{c}\text { Chen et al. } \\
\text { [116] }\end{array}$ \\
\hline Paclitaxel & $\begin{array}{l}\text { SKOV-3 (epithelial ovarian } \\
\text { cancer) }\end{array}$ & $\begin{array}{l}\text { Increased expression of KLK4 favors } \\
\text { multicellular aggregates formation } \\
\text { and these are more resistant to } \\
\text { drug. }\end{array}$ & Increased expression of KLK4. & $\begin{array}{l}\text { Dong et al. } \\
{[115]}\end{array}$ \\
\hline $\begin{array}{l}\text { Doxorubicin/ } \\
\text { Cisplatin }\end{array}$ & $\begin{array}{l}\text { SW1353, CH2879, JJ012, } \\
\text { OUMS27 (chondrosarcoma } \\
\text { cell lines) }\end{array}$ & $\begin{array}{l}\text { In 3D models doxorubicin can } \\
\text { reach cell's nuclei but cells are } \\
\text { more resistant to the drug. }\end{array}$ & $\begin{array}{l}\text { Drug penetration is not dependent on MDR } \\
\text { activity. Bcl- } 2 \text { members are important to } \\
\text { resistance. }\end{array}$ & $\begin{array}{l}\text { Van } \\
\text { Oosterwijk } \\
\text { et al. [29] }\end{array}$ \\
\hline Taxol/Cisplatin & $\begin{array}{l}\text { HEY, A2780, SKOV3, OVAC429 } \\
\text { (human ovarian cancer) }\end{array}$ & $\begin{array}{l}\text { Cells cultured in } 3 \mathrm{D} \text { are more } \\
\text { resistant to taxol treatment. }\end{array}$ & $\begin{array}{l}\text { Cells from some cell lines did not arrested in } \\
\text { G2-M after taxol treatment. }\end{array}$ & $\begin{array}{l}\text { Frankel } \\
\text { et al. [144] }\end{array}$ \\
\hline Doxorubicin & $\begin{array}{l}\text { HepG2 (human hepatocellular } \\
\text { liver carcinoma) and } 3 T 3-\mathrm{J} 2 \\
\text { (fibroblasts murine stromal } \\
\text { cells) }\end{array}$ & $\begin{array}{l}\text { Increased cell viability in } 3 \mathrm{D} .3 \mathrm{D} \\
\text { heterospheroids are more resistant } \\
\text { than } 2 \mathrm{D} \text { and homospheroid } \\
\text { models. }\end{array}$ & $\begin{array}{l}\text { Stromal fibroblasts and collagen hydrogel } \\
\text { culture system provides more resistance. }\end{array}$ & $\begin{array}{l}\text { Yip \& Cho } \\
{[105]}\end{array}$ \\
\hline Doxorubicin & HT1080 (human fibrosarcoma) & $\begin{array}{l}\text { In } 2 \mathrm{D} \text { doxorubicin decreased cell } \\
\text { migration, and in } 3 \mathrm{D} \text { the drug did } \\
\text { not affeted cell migration. }\end{array}$ & $\begin{array}{l}\text { EMC proteins in a } 3 D \text { configuration are able to } \\
\text { protect cancer cells from the antimigratory } \\
\text { effect of doxorrubicin. Environment-mediated } \\
\text { drug resistance. }\end{array}$ & $\begin{array}{c}\text { Millerot- } \\
\text { Serrurot } \\
{[106]}\end{array}$ \\
\hline $\begin{array}{l}\text { Docetaxel/ } \\
\text { Cisplatin/5-FU/ } \\
\text { Gemcitabine/ } \\
\text { Camptothecin }\end{array}$ & $\begin{array}{l}\text { H460, A549, H1650 (lung } \\
\text { cancer) }\end{array}$ & $\begin{array}{l}\text { All drugs showed increased IC-50 in } \\
\text { 3D. }\end{array}$ & $\begin{array}{l}\text { Caspase- } 3 \text { is decreased in 3D. Drugs could not } \\
\text { penetrated into cells in } 3 D \text { and apoptosis was } \\
\text { decreased. }\end{array}$ & $\begin{array}{l}\text { Godugu } \\
\text { et al. [107] }\end{array}$ \\
\hline
\end{tabular}

The table shows authors that compared effects in $2 \mathrm{D}$ and $3 \mathrm{D}$ cell cultures in the same article.

transmembrane glycoprotein believed to be activated in a wide range of tumors in which it plays a critical role in cancer cell adhesion, migration, invasion and survival [154]. It is a multifunctional cell surface adhesion molecule associated with cell-cell and cell-matrix interaction. CD44+ has identified cells with the ability of give rise to new tumors in vivo, in different types of cancer. Patient samples of head and neck squamous cell carcinoma (HNSCC), for example, contain a heterogeneous population of cancer cells and the small subpopulation CD44+ contained most of the CSCs, evidenced by its tumorigenic potential in immunodeficient mice [155].

CD133 (prominin-1 or AC133) was originally described in human hematopoietic stem cells and has subsequently been used as a marker to isolate CSCs from many tumor types. It is a member of the pentaspan transmembrane glycoprotein family involved in a variety of cellular activities. CD133 is found to be selectively localized in microvilli and other plasma membrane protrusions irrespectively of cell type and interact with membrane cholesterol. Wnt, Notch, TGF $\beta 1$, Line-1 and methylation regulate its expression. CD133 is involved in energy metabolism and in autophagy, which are beneficial for the survival of cancer stem cells.

ALDH activity is an important functional marker of normal and malignant stem/progenitor cells. ALDHs contribute to drug resistance through detoxification of many cytotoxic agents provided that aldehydes are generated by several metabolic processes (reviewed by Marchitti et al. [156]). Increased ALDH activity in hematopoietic stem cells, for example, contributes to metabolize and detoxify cyclophosphamide [157]. The ALDH family of enzymes comprises 19 isoforms that can be found in different cell compartments: nucleus, cytoplasm or mitochondria. In a retrospective analysis of breast cancer patient samples, ALDH1A1, but not ALDH3A1, expression was found to be predictive of tumor responsiveness to cyclophosphamide and other oxazaphosphorines treatment [158]. In support of this potential role for ALDH in CSC resistance to chemotherapeutics, CSC enrichment was observed in colorectal cancer xenograft tumors after 
cyclophosphamide treatment, and this was correlated with enhanced ALDH1A1 expression and enzymatic activity.

Antibodies against the ALDH enzyme family are available, but the vast majority of studies have used cellsorting techniques to enrich for cells expressing these enzymes. Live cells expressing high ALDH activity are usually identified by the Aldefluor assay and sorted by fluorescence-activated cell sorting. This approach was used by Cheung et al. [159] in one of the first studies isolating ALDH+ cells from acute myeloid leukemia. ADLH+ enriched cell population was similarly isolated from breast cancer [160]. In both studies, the isolated cells presented self-renewal ability and high tumorigenic potential. ADLH+ cells with CSC phenotype were isolated from several hematopoietic and solid tumors including lung, liver, bone, colon, pancreatic, ovarian, head and neck, and prostate cancers.

The aldefluor activity specific for the CSCs of these cancers has been attributed to ALDH1A1 and so prognostic studies have been targeted to this isoform. However, Marcato et al. [161] claim that ALDH1A3 and other ALDH isoforms activities contribute to aldefluor positivity.

Additionally, ALDHs participate in ester hydrolysis and act as antioxidant. Enzymatic aldehyde dehydrogenase activity of some specific isoforms is important for the preservation of undifferentiated stem cells, by interfering with the biosynthesis of endogenous retinoic acid (RA) through the oxidation of all-trans-retinal and 9-cisretinal. The cytosolic isoform ALDH1A1, associated with metabolism and detoxification of cyclophosphamide, plays a role in the differentiation of several cell types through the oxidation of retinal to RA [156].

RA modulates biological processes like cell proliferation, differentiation, cell cycle arrest and apoptosis. Alltrans-RA is used to treat acute promyelocytic leukemia, since it induces differentiation of immature leukemia blasts into terminally differentiated granulocytes, leading to a clinical remission in approximately $90 \%$ of patients. Based on these results, retinoic acid effects are being studied in other cancers and cancer cell lines. The combined use of RA $(0.1 \mu \mathrm{M})$ and cAMP $(1 \mathrm{mM})$, an important second messenger, improves the responsiveness of hepatocarcinoma cell line (HTC) to RA treatment. RA and cAMP were effective in inhibiting the proliferation of HTC cells independently of combined use. However, treatment with RA and cAMP increased Ecadherin, Cx26, Cx32 and Ser9-GSK-3 $\beta$ (inactive form) expression while the expression of Cx43, Tyr216-GSK$3 \beta$ (active form) and phosphorylated ERK decreased, showing that the combined use of RA and cAMP is more effective in inducing differentiation [162].

The use of the vital dye Hoechst 33342 exclusion as a method to isolate normal hematopoietic stem cells was proposed by Goodell et al. [163]. The method defines an easily identifiable and highly reproducible small cell population $(0.1 \%$ of bone marrow cells), presenting stem cell phenotype. The Hoechst-exclusion SP assay has the advantage of measuring a functional parameter of the cells. Widely used in hematological malignancies, the methodological approach requires additional steps such as enzymatic cell disaggregation for solid tumor samples analyses [164]. Both normal and cancer stem cells express the $\mathrm{ABC}$ transporters. The $\mathrm{ABC}$ domain of these transmembrane proteins allows ATP binding and hydrolysis, and the $\mathrm{ABC}$ protein can function as receptor, channel and multidrug transporter, participating in the efflux of small molecules. These pumps detoxify cells through the efflux of cytotoxic agents, being responsible for the exclusion of the dye Hoechst 33342.

SP cells were isolated and characterized in most human cancers including HNSCC, bladder, ovarian, pancreas, lung, hepatocellular carcinomas, osteosarcoma and Ewing's (for review, see Tirino et al. [164]). SP cells were consistently shown to represent a stem cell-enriched population. Compared to non-SP cells, a smaller number of SP cells are able to grow as tumors when injected in immunodeficient (NOD/SCID) mice.

Breast cancer cell lines, like MDA-MB-231 and MCF-7, show anoikis-resistance in drug treatments with doxorubicin. The SP cells fraction in the anoikis-resistant cancer cells seems to be higher than the parental cells [165]. There are reported mechanisms that contribute to SP chemoresistance including relative quiescence, expression of $\mathrm{ABC}$ transporters and/or MDR1, a more efficient DNA-repair capability, and the elevated expression of anti-apoptotic proteins.

The high tumorigenic efficiency of SP cells is associated with drug resistance and with the presence of other CSC markers, such as ALDH+, CD133+ or CD44+. He et al. (2013) proposed the phenotypical modulation of CSCs, which involves the conversion of SP to non-SP cells (and vice versa), to be under PI3k/AKT and $\beta$-catenin /CBP signaling pathway. Beta-catenin accumulation enhanced the transition from non-SP to SP phenotype, and siRNA against any of the downstream signals abrogated the conversion of non-SP to SP cells in breast and bladder cancer cell lines.

Other method for CSC isolation was based on the observations of Reynolds et al. [166] that some cells of the central nervous system were able to grow in suspension when plated on non-adherent surface, forming structures named spheres or neurospheres. These floating colonies were able to self-renewal, once when enzymatically dissociated, they originated several new spheres. Their stem cell phenotype was confirmed by the ability to originate different cell types under adequate stimulation (astrocytes, neuron or oligodendrocytes). The floating 
sphere formation is consequence of the ability to grow independently of surface anchorage and resistance to anoikis associated with high clonogenicity, features shared by both normal and cancer stem cells.

Spheres were grown from different human cancer samples and cancer cell cultures and they consisted mainly of CSCs (review in Alamgeeret al. [167]). SCLC and NSCLCCD133+ cells, when submitted to long-term culture as spheres, could modify their phenotype to CD133- cells [153]. The phenotype modulation of CSCs is important to define more efficient therapies. MCF-7 cell line long-term spheroids showed high degree of cell differentiation, organizing duct-like structures [119].

The CSC model represents a very important tool in cancer biology, especially in relation to the problem of drug resistance. CSC/TIC cells may exist independently of the described markers and the cellular plasticity may be much more relevant. Nevertheless, the current identification of markers and pathways is already underpinning some novel developments in therapeutic strategies for patients with cancer.

\section{Conclusions}

The resistance to chemotherapy was described in cancer longtime ago, being responsible for most of treatment failures. Remarkable progress has been achieved in understanding the tumorigenesis and cancer progression molecular mechanisms, contributing to the elucidation of some aspects associated with lack of response to treatment. Traditionally, it has been proposed that genetic instability would be responsible for generation of drug resistant tumor cells, according to the clonal theory of cancer development. Alternatively, cancer cells present different mechanisms of drug resistance including innate mechanisms that operate at stem cells and functional responses that result in modulation of intracellular signaling pathways. The major contribution of the study of the drug resistance mechanisms is the definition and implementation of more effective, and perhaps personalized, treatment protocols. Multiple sensitization using natural products and combined protocols are currently in use to reduce or deplete the resistance; however the establishment of 3D cell cultures, a system closer to the in vivo tumor, would represent a valuable tool to cancer treatment.

\footnotetext{
Abbreviations

2D: Two-dimensional; 3D: Three-dimensional; 5-FU: 5-fluorouracil; ABC: ATP-binding cassette; Akt: Protein kinase B; ALDH: Aldehyde dehydrogenase; CSC: Cancer stem cell; CSCs: Cancer stem cells; ECM: Extracellular matrix; HNSCC: Head and neck squamous cell carcinoma; IKB: Inhibitor of nuclear factor KB; IKK: IKB kinase; KLK4: High tumor kallikrein-related peptidase 4; MDR: Multidrug resistance; MiRNAs: Micro RNAs; MRP1: Multidrug resistance associated protein 1; NF-kB: Nuclear factor KB; P-gp: P-glycoprotein; PI3K: Phosphatidylinositol 3-kinase; RA: Retinoic acid; SP: Side-population; TICs: Tumor initiating cells.
}

Competing interests

The authors declare that they have no competing interests.

\section{Authors' contributions}

ELON and GMM-S were the main authors of the manuscript; AAM, BAC, BR-S, CL, ELON, JHN, MSU, MMS, PR-T and GMM-S collected and studied the bibliography and drafted the manuscript; ELON and GMM-S revised the manuscript critically for important intellectual content. All authors read and approved the final manuscript.

\section{Acknowledgements}

We thank Roberdo Cabado for helping with the Figure 1 final art. The works of our laboratory are supported by FAPESP, CNPq and CAPES.

Received: 6 February 2014 Accepted: 20 March 2014

Published: 28 April 2014

\section{References}

1. Christakis P: The birth of chemotherapy at Yale. Bicentennial lecture series: Surgery Grand Round. Yale J Biol Med 2011, 84:169-172.

2. Miller DR: A tribute to Sidney Farber- the father of modern chemotherapy. Br J Haematol 2006, 134:20-26.

3. Frei $E$, Freireich $E$, Gehan E: Studies of sequential and combination antimetabolite therapy in acute leukemia: 6-mercaptopurine and methotrexate. Blood 1961, 18:431-454.

4. Freireich E, Gehan E: The effect of 6-mercaptopurine on the duration of steroid-induced remissions in acute leukemia: a model for evaluation of other potentially useful therapy. Blood 1963, 21:699-716.

5. Frei E, Karon M, Levin RH, Freireich EJ, Taylor RJ, Hananian J, Selawry O, Holland JF, Hoogstraten B, Wolman IJ, Abir E, Sawitsky A, Lee S, Mills SD, Burgert EO, Spurr CL, Patterson RB, Ebaugh FG, James GW, Moon JH: The effectiveness of combinations of antileukemic agents in inducing and maintaining remission in children with acute leukemia. Blood 1965, 26:642-656

6. DeVita VT, Chu E: A history of cancer chemotherapy. Cancer Res 2008, 68:8643-8653.

7. LAW LW: Origin of the resistance of leukaemic cells to folic acid antagonists. Nature 1952, 169:628-629.

8. Luria SE, Delbrück M: Mutations of bacteria from virus sensitivity to virus resistance. Genetics 1943, 28:491-511.

9. Chen Y, Liu H, Wu W, Li Y, Li J: Osteopontin genetic variants are associated with overall survival in advanced non-small-cell lung cancer patients and bone metastasis. J Exp Clin Cancer Res 2013, 32:45.

10. Wang $N$, Zhang $H$, Yao Q, Wang Y, Dai S, Yang X: TGFBI promoter hypermethylation correlating with paclitaxel chemoresistance in ovarian cancer. J Exp Clin Cancer Res 2012, 31:6.

11. Wang G, Zhang J, Liu L, Sharma S, Dong Q: Quercetin potentiates doxorubicin mediated antitumor effects against liver cancer through p53/Bcl-xl. PLoS One 2012, 7:e51764.

12. Goldenberg GJ, Begleiter A: Membrane transport of alkylating agents. Pharmacol Ther 1980, 8:237-274.

13. Fry DW, Jackson RC: Membrane transport alterations as a mechanism of resistance to anticancer agents. Cancer Surv 1986, 5:47-79.

14. Kessel D, Botterill V, Wodinsky I: Uptake and retention of daunomycin by mouse leukemic cells as factors in drug response. Cancer Res 1968, 28:938-941.

15. Nowell PC: The clonal evolution of tumor cell populations. Science 1976, 194:23-28.

16. Lapidot T, Sirard C, Vormoor J, Murdoch B, Hoang T, Caceres-Cortes J, Minden M, Paterson B, Caligiuri MA, Dick JE: A cell initiating human acute myeloid leukaemia after transplantation into SCID mice. Nature 1994, 367:645-648.

17. Bonnet D, Dick JE: Human acute myeloid leukemia is organized as a hierarchy that originates from a primitive hematopoietic cell. Nat Med 1997, 3:730-737.

18. Visvader JE, Lindeman GJ: Cancer stem cells: current status and evolving complexities. Cell Stem Cell 2012, 10:717-728.

19. Bai J, Sui J, Demirjian A, Vollmer CM, Marasco W, Callery MP: Predominant $\mathrm{BCl}$-XL knockdown disables antiapoptotic mechanisms: tumor necrosis factor-related apoptosis-inducing ligand-based triple chemotherapy 
overcomes chemoresistance in pancreatic cancer cells in vitro. Cancer Res 2005, 65:2344-2352.

20. Wang W, Cassidy J: Constitutive nuclear factor-kappa B mRNA, protein overexpression and enhanced DNA-binding activity in thymidylate synthase inhibitor-resistant tumour cells. Br J Cancer 2003, 88:624-629.

21. Wang W, McLeod HL, Cassidy J: Disulfiram-mediated inhibition of NFkappaB activity enhances cytotoxicity of 5-fluorouracil in human colorectal cancer cell lines. Int J Cancer 2003, 104:504-511.

22. Januchowski R, Wojtowicz K, Sujka-Kordowska P, Andrzejewska M, Zabel M: MDR gene expression analysis of six drug-resistant ovarian cancer cell lines. Biomed Res Int 2013, 2013:241763.

23. Krishan A, Fitz CM, Andritsch I: Drug retention, efflux, and resistance in tumor cells. Cytometry 1997, 29:279-285.

24. Aran JM, Gottesman MM, Pastan I: Drug-selected coexpression of human glucocerebrosidase and P-glycoprotein using a bicistronic vector. Proc Natl Acad Sci U S A 1994, 91:3176-3180.

25. Munoz M, Henderson M, Haber M, Norris M: Role of the MRP1/ABCC1 multidrug transporter protein in cancer. IUBMB Life 2007, 59:752-757.

26. Abdulhussein AA, Wallace HM: Polyamines and membrane transporters. Amino Acids 2013, 46:655-660.

27. Thiebaut F, Tsuruo T, Hamada H, Gottesman MM, Pastan I, Willingham MC: Cellular localization of the multidrug-resistance gene product P-glycoprotein in normal human tissues. Proc Natl Acad Sci U S A 1987, 84:7735-7738.

28. Jelly ND, Hussain II, Eremin J, Eremin O, El-Sheemy M: The stem cell factor antibody enhances the chemotherapeutic effect of adriamycin on chemoresistant breast cancer cells. Cancer Cell Int 2012, 12:21.

29. Kalalinia F, Elahian F, Hassani M, Kasaeeian J, Behravan J: Phorbol ester TPA modulates chemoresistance in the drug sensitive breast cancer cell line MCF-7 by inducing expression of drug efflux transporter ABCG2. Asian Pac J Cancer Prev 2012, 13:2979-2984.

30. Ferreira PA, Ruela-de-Sousa RR, Queiroz KCS, Souza ACS, Milani R, Pilli RA Peppelenbosch MP, den Hertog J, Ferreira CV: Knocking down low molecular weight protein tyrosine phosphatase (LMW-PTP) reverts chemoresistance through inactivation of Src and Bcr-Abl proteins. PLOS One 2012, 7:e44312.

31. Van Oosterwijk JG, Herpers B, Meijer D, Briaire-de Bruijn IH, Cleton-Jansen AM, Gelderblom H, van de Water B, Bovée JVMG: Restoration of chemosensitivity for doxorubicin and cisplatin in chondrosarcoma in vitro: BCL-2 family members cause chemoresistance. Ann Oncol 2012, 23:1617-1626

32. Sui H, Fan Z-Z, Li Q: Signal transduction pathways and transcriptional

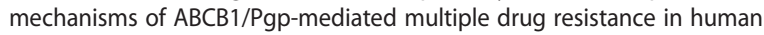
cancer cells. J Int Med Res 2012, 40:426-435.

33. Zöchbauer-Müller S, Filipits M, Rudas M, Brunner R, Krajnik G, Suchomel R, Schmid K, Pirker R: P-glycoprotein and MRP1 expression in axillary lymph node metastases of breast cancer patients. Anticancer Res 2001 21:119-124.

34. dit Faute MA, Laurent L, Ploton D, Poupon M-F, Jardillier J-C, Bobichon H: Distinctive alterations of invasiveness, drug resistance and cell-cell organization in 3D-cultures of MCF-7, a human breast cancer cell line, and its multidrug resistant variant. Clin Exp Metastasis 2002, 19:161-168.

35. Shi Y, Liu C, Liu X, Tang DG, Wang J: The microRNA miR-34a inhibits nonsmall cell lung cancer (NSCLC) growth and the CD44hi stem-like NSCLC cells. PLoS One 2014, 9:e90022.

36. Markova SM, Kroetz DL: ABCC4 is regulated by microRNA-124a and microRNA-506. Biochem Pharmacol 2014, 87:515-522.

37. Jiao X, Zhao L, Ma M, Bai X, He M, Yan Y, Wang Y, Chen Q, Zhao X, Zhou M, Cui Z, Zheng Z, Wang E, Wei M: MiR-181a enhances drug sensitivity in mitoxantone-resistant breast cancer cells by targeting breast cancer resistance protein (BCRP/ABCG2). Breast Cancer Res Treat 2013, 139:717-730.

38. Skulachev VP: Cytochrome $\mathrm{C}$ in the apoptotic and antioxidant cascades. FEBS Lett 1998, 423:275-280.

39. Fichtinger-Schepman AM, van Oosterom AT, Lohman PH, Berends F: cis-Diamminedichloroplatinum (II)-induced DNA adducts in peripheral leukocytes from seven cancer patients: quantitative immunochemical detection of the adduct induction and removal after a single dose of cis-diamminedichloroplatinum (II). Cancer Res 1987, 47:3000-3004.

40. Reed E, Litterst CL, Thill CC, Yuspa SH, Poirier MC: cis-Diamminedichloroplatinum (II)-DNA adduct formation in renal, gonadal, and tumor tissues of male and female rats. Cancer Res 1987, 47:718-722.
41. Eckstein N: Platinum resistance in breast and ovarian cancer cell lines. J Exp Clin Cancer Res 2011, 30:91.

42. De Brabander M, Geuens G, Nuydens R, Willebrords R, De Mey J: Taxol induces the assembly of free microtubules in living cells and blocks the organizing capacity of the centrosomes and kinetochores. Proc Natl Acad Sci U S A 1981, 78:5608-5612.

43. Long BH, Fairchild CR: Paclitaxel inhibits progression of mitotic cells to G1 phase by interference with spindle formation without affecting other microtubule functions during anaphase and telophase. Cancer Res 1994 54:4355-4361.

44. Wallace-Brodeur RR, Lowe SW: Clinical implications of p53 mutations. Cell Mol Life Sci 1999, 55:64-75

45. Satyamoorthy K, Bogenrieder T, Herlyn M: No longer a molecular black box-new clues to apoptosis and drug resistance in melanoma. Trends Mol Med 2001, 7:191-194.

46. Karin M, Cao Y, Greten FR, Li Z-W: NF-kappaB in cancer: from innocent bystander to major culprit. Nat Rev Cancer 2002, 2:301-310.

47. Lee DH, Macintyre JP, Taylor GR, Wang E, Plante RK, Tam SS, Pope BL, Lau CY: Tepoxalin enhances the activity of an antioxidant, pyrrolidine dithiocarbamate, in attenuating tumor necrosis factor alpha-induced apoptosis in WEHI 164 cells. J Pharmacol Exp Ther 1999, 289:1465-1471.

48. Pahl HL: Activators and target genes of Rel/NF-kappaB transcription factors. Oncogene 1999, 18:6853-6866.

49. Voboril R, Hochwald SN, Li J, Brank A, Weberova J, Wessels F, Moldawer LL, Camp ER, Mackay SLD: Inhibition of NF-kappa B augments sensitivity to 5 -fluorouracil/folinic acid in colon cancer. J Surg Res 2004, 120:178-188.

50. El-Rayes BF, Ali S, Ali IF, Philip PA, Abbruzzese J, Sarkar FH: Potentiation of the effect of erlotinib by genistein in pancreatic cancer: the role of Akt and nuclear factor-kappaB. Cancer Res 2006, 66:10553-10559.

51. Arlt A, Gehrz A, Müerköster S, Vorndamm J, Kruse M, Fölsch UR, Schäfer H: Role of NF-kappaB and Akt/PI3K in the resistance of pancreatic carcinoma cell lines against gemcitabine-induced cell death. Oncogene 2003, 22:3243-3251.

52. Banerjee S, Wang Z, Kong D, Sarkar FH: 3,3'-Diindolylmethane enhances chemosensitivity of multiple chemotherapeutic agents in pancreatic cancer. Cancer Res 2009, 69:5592-5600.

53. Müerköster S, Arlt A, Witt M, Gehrz A, Haye S, March C, Grohmann F, Wegehenkel K, Kalthoff H, Fölsch UR, Schäfer H: Usage of the NF-kappaB inhibitor sulfasalazine as sensitizing agent in combined chemotherapy of pancreatic cancer. Int J Cancer 2003, 104:469-476.

54. Long J, Zhang Y, Yu X, Yang J, LeBrun DG, Chen C, Yao Q, Li M: Overcoming drug resistance in pancreatic cancer. Expert Opin Ther Targets 2011, 15:817-828.

55. Wang Y-W, Wang S-J, Zhou Y-N, Pan S-H, Sun B: Escin augments the efficacy of gemcitabine through down-regulation of nuclear factor-kB and nuclear factor-KB-regulated gene products in pancreatic cancer both in vitro and in vivo. J Cancer Res Clin Oncol 2012, 138:785-797.

56. Xiao G, Wei J: Effects of beta-Aescin on the expression of nuclear factorkappaB and tumor necrosis factor-alpha after traumatic brain injury in rats. J Zhejiang Univ Sci B 2005, 6:28-32.

57. Harikumar KB, Sung B, Pandey MK, Guha S, Krishnan S, Aggarwal BB: Escin, a pentacyclic triterpene, chemosensitizes human tumor cells through inhibition of nuclear factor-kappaB signaling pathway. Mol Pharmacol 2010, 77:818-827.

58. Patlolla JMR, Raju J, Swamy MV, Rao CV: Beta-escin inhibits colonic aberrant crypt foci formation in rats and regulates the cell cycle growth by inducing p21(waf1/cip1) in colon cancer cells. Mol Cancer Ther 2006, 5:1459-1466.

59. Tan SM, Li F, Rajendran P, Kumar AP, Hui KM, Sethi G: Identification of beta-escin as a novel inhibitor of signal transducer and activator of transcription 3/Janus-activated kinase 2 signaling pathway that suppresses proliferation and induces apoptosis in human hepatocellular carcinoma cells. J Pharmacol Exp Ther 2010, 334:285-293.

60. Ji DB, Xu B, Liu JT, Ran FX, Cui JR: $\beta$-Escin sodium inhibits inducible nitric oxide synthase expression via downregulation of the JAK/STAT pathway in A549 cells. Mol Carcinog 2011, 50:945-960.

61. Shen D-Y, Kang J-H, Song W, Zhang W-Q, Li W-G, Zhao Y, Chen Q-X: Apoptosis of human cholangiocarcinoma cell lines induced by $\beta$-escin through mitochondrial caspase-dependent pathway. Phytother Res 2011, 25:1519-1526. 
62. Barr MP, Gray SG, Hoffmann AC, Hilger RA, Thomale J, O'Flaherty JD, Fennell DA, Richard D, O'Leary JJ, O'Byrne KJ: Generation and characterisation of cisplatin-resistant non-small cell lung cancer cell lines displaying a stemlike signature. PLoS One 2013, 8:e54193.

63. Li Y, Ahmed F, Ali S, Philip PA, Kucuk O, Sarkar FH: Inactivation of nuclear factor kappaB by soy isoflavone genistein contributes to increased apoptosis induced by chemotherapeutic agents in human cancer cells. Cancer Res 2005, 65:6934-6942.

64. Fraser M, Leung B, Jahani-Asl A, Yan X, Thompson WE, Tsang BK: Chemoresistance in human ovarian cancer: the role of apoptotic regulators. Reprod Biol Endocrinol 2003, 1:66

65. Mabuchi S, Ohmichi M, Nishio Y, Hayasaka T, Kimura A, Ohta T, Kawagoe J, Takahashi K, Yada-Hashimoto N, Seino-Noda H, Sakata M, Motoyama T, Kurachi H, Testa JR, Tasaka K, Murata Y: Inhibition of inhibitor of nuclear factor-kappaB phosphorylation increases the efficacy of paclitaxel in in vitro and in vivo ovarian cancer models. Clin Cancer Res 2004, 10:7645-7654

66. Nakanishi C, Toi M: Nuclear factor-kappaB inhibitors as sensitizers to anticancer drugs. Nat Rev Cancer 2005, 5:297-309.

67. Kim S-H, Juhnn Y-S, Song Y-S: Akt involvement in paclitaxel chemoresistance of human ovarian cancer cells. Ann N Y Acad Sci 2007 1095:82-89.

68. Aggarwal BB, Shishodia S, Takada Y, Banerjee S, Newman RA, Bueso-Ramos CE, Price JE: Curcumin suppresses the paclitaxel-induced nuclear factor-kappaB pathway in breast cancer cells and inhibits lung metastasis of human breast cancer in nude mice. Clin Cancer Res 2005, 11:7490-7498.

69. Notarbartolo M, Poma P, Perri D, Dusonchet L, Cervello M, D'Alessandro N: Antitumor effects of curcumin, alone or in combination with cisplatin or doxorubicin, on human hepatic cancer cells. Analysis of their possible relationship to changes in NF-kB activation levels and in IAP gene expression. Cancer Lett 2005, 224:53-65.

70. Li M, Zhang Z, Hill DL, Wang H, Zhang R: Curcumin, a dietary component has anticancer, chemosensitization, and radiosensitization effects by down-regulating the MDM2 oncogene through the PI3K/mTOR/ETS2 pathway. Cancer Res 2007, 67:1988-1996.

71. Zambonin L, Caliceti C, Vieceli Dalla Sega F, Fiorentini D, Hrelia S, Landi L, Prata C: Dietary phenolic acids act as effective antioxidants in membrane models and in cultured cells, exhibiting proapoptotic effects in leukaemia cells. Oxid Med Cell Longev 2012, 2012:839298.

72. Niero ELDO, Machado-Santelli GM: Cinnamic acid induces apoptotic cell death and cytoskeleton disruption in human melanoma cells. J Exp Clin Cancer Res 2013, 32:31.

73. Tomizawa A, Kanno S, Osanai Y, Goto A, Sato C, Yomogida S, Ishikawa M: Induction of apoptosis by a potent caffeic acid derivative, caffeic acid undecyl ester, is mediated by mitochondrial damage in NALM-6 human B cell leukemia cells. Oncol Rep 2013, 29:425-429.

74. Yang Y-I, Lee K-T, Park H-J, Kim TJ, Choi YS, Shih I-M, Choi J-H: Tectorigenin sensitizes paclitaxel-resistant human ovarian cancer cells through downregulation of the Akt and NFKB pathway. Carcinogenesis 2012, 33:2488-2498

75. Arafa E-SA, Zhu Q, Barakat BM, Wani G, Zhao Q, El-Mahdy MA, Wani AA: Tangeretin sensitizes cisplatin-resistant human ovarian cancer cells through downregulation of phosphoinositide 3-kinase/Akt signaling pathway. Cancer Res 2009, 69:8910-8917.

76. Datta S, Brunet A, Greenberg M: Cellular survival: a play in three Akts. Genes Dev 1999, 13:2905-2927.

77. Yuan ZQ, Sun M, Feldman RI, Wang G, Ma X, Jiang C, Coppola D, Nicosia SV Cheng JQ: Frequent activation of AKT2 and induction of apoptosis by inhibition of phosphoinositide-3-OH kinase/Akt pathway in human ovarian cancer. Oncogene 2000, 19:2324-2330

78. Sun $M$, Wang G, Paciga JE, Feldman RI, Yuan ZQ, Ma XL, Shelley SA, Jove $R$, Tsichlis PN, Nicosia SV, Cheng JQ: AKT1/PKBalpha kinase is frequently elevated in human cancers and its constitutive activation is required for oncogenic transformation in NIH3T3 cells. Am J Pathol 2001, 159:431-437.

79. Sun M, Paciga JE, Feldman RI, Yuan Z, Coppola D, Lu YY, Shelley SA, Nicosia SV, Cheng JQ: Phosphatidylinositol-3-OH Kinase (PI3K)/AKT2, activated in breast cancer, regulates and is induced by estrogen receptor alpha (ERalpha) via interaction between ERalpha and PI3K. Cancer Res 2001, 61:5985-5991.
80. Sos ML, Koker M, Weir BA, Heynck S, Rabinovsky R, Zander T, Seeger JM, Weiss J, Fischer F, Frommolt P, Michel K, Peifer M, Mermel C, Girard L, Peyton M, Gazdar AF, Minna JD, Garraway LA, Kashkar H, Pao W, Meyerson $M$, Thomas RK: PTEN loss contributes to erlotinib resistance in EGFRmutant lung cancer by activation of Akt and EGFR. Cancer Res 2009, 69:3256-3261.

81. O'Brien NA, Browne BC, Chow L, Wang Y, Ginther C, Arboleda J, Duffy MJ, Crown J, O'Donovan N, Slamon DJ: Activated phosphoinositide 3-kinase/ AKT signaling confers resistance to trastuzumab but not lapatinib. $\mathrm{Mol}$ Cancer Ther 2010, 9:1489-1502.

82. Chen K-F, Chen H-L, Tai W-T, Feng W-C, Hsu C-H, Chen P-J, Cheng A-L: Activation of phosphatidylinositol 3-kinase/Akt signaling pathway mediates acquired resistance to sorafenib in hepatocellular carcinoma cells. J Pharmacol Exp Ther 2011, 337:155-161.

83. Lin F-C, Liu Y-P, Lai C-H, Shan Y-S, Cheng H-C, Hsu P-I, Lee C-H, Lee Y-C, Wang H-Y, Wang C-H, Cheng JQ, Hsiao M, Lu P-J: RUNX3-mediated transcriptional inhibition of Akt suppresses tumorigenesis of human gastric cancer cells. Oncogene 2012, 31:4302-4316.

84. Zheng Y, Wang R, Song H-Z, Pan B-Z, Zhang Y-W, Chen L-B: Epigenetic downregulation of RUNX3 by DNA methylation induces docetaxel chemoresistance in human lung adenocarcinoma cells by activation of the AKT pathway. Int J Biochem Cell Biol 2013, 45:1-10.

85. Liu B-N, Yan H-Q, Wu X, Pan Z-H, Zhu Y, Meng Z-W, Zhou Q-H, Xu K. Apoptosis induced by benzyl isothiocyanate in gefitinib-resistant lung cancer cells is associated with Akt/MAPK pathways and generation of reactive oxygen species. Cell Biochem Biophys 2013, 66:81-92.

86. Gao A-M, Ke Z-P, Wang J-N, Yang J-Y, Chen S-Y, Chen H: Apigenin sensitizes doxorubicin-resistant hepatocellular carcinoma BEL-7402/ADM cells to doxorubicin via inhibiting PI3K/Akt/Nrf2 pathway. Carcinogenesis 2013, 34:1806-1814

87. Frisch SM, Francis $\mathrm{H}$ : Disruption of epithelial cell-matrix interactions induces apoptosis. J Cell Biol 1994, 124:619-626.

88. Stoker M, O'Neill C, Berryman S, Waxman V: Anchorage and growth regulation in normal and virus-transformed cells. Int J Cancer 1968 3:683-693.

89. Liotta LA, Kohn E: Anoikis: cancer and the homeless cell. Nature 2004, 430:973-974.

90. Frisch SM, Screaton RA: Anoikis mechanisms. Curr Opin Cell Biol 2001, 13:555-562.

91. Martin SS, Leder P: Human MCF10A mammary epithelial cells undergo apoptosis following actin depolymerization that is independent of attachment and rescued by Bcl-2. Mol Cell Biol 2001, 21:6529-6536.

92. Schmidt M, Hövelmann S, Beckers TL, Ho S: A novel form of constitutively active farnesylated Akt1 prevents mammary epithelial cells from anoikis and suppresses chemotherapy-induced apoptosis. Br J Cancer 2002, 87:924-932.

93. Duxbury MS, Ito H, Benoit E, Waseem T, Ashley SW, Whang EE: A novel role for carcinoembryonic antigen-related cell adhesion molecule 6 as a determinant of gemcitabine chemoresistance in pancreatic adenocarcinoma cells. Cancer Res 2004, 64:3987-3993.

94. Díaz-Montero CM, Mclntyre BW: Acquisition of anoikis resistance in human osteosarcoma cells does not alter sensitivity to chemotherapeutic agents. BMC Cancer 2005, 5:39.

95. Cittelly DM, Dimitrova I, Howe EN, Cochrane DR, Jean A, Spoelstra NS, Post MD, Lu X, Broaddus RR, Spillman MA, Richer JK: Restoration of miR-200c to ovarian cancer reduces tumor burden and increases sensitivity to paclitaxel. Mol Cancer Ther 2012, 11:2556-2565.

96. Lindquist S, Craig EA: The heat-shock proteins. Annu Rev Genet 1988, 22:631-677.

97. Frydman J, Nimmesgern E, Ohtsuka K, Hartl FU: Folding of nascent polypeptide chains in a high molecular mass assembly with molecular chaperones. Nature 1994, 370:111-117.

98. Hernández MP, Chadli A, Toft DO: HSP40 binding is the first step in the HSP90 chaperoning pathway for the progesterone receptor. J Biol Chem 2002, 277:11873-11881.

99. Jeong $\mathrm{C}-\mathrm{H}$, Park HB, Jang WJ, Jung SH, Seo YH: Discovery of hybrid Hsp90 inhibitors and their anti-neoplastic effects against gefitinib-resistant nonsmall cell lung cancer (NSCLC). Bioorg Med Chem Lett 2014, 24:224-227.

100. Sang J, Acquaviva J, Friedland JC, Smith DL, Sequeira M, Zhang C, Jiang Q, Xue L, Lovly CM, Jimenez J-P, Shaw AT, Doebele RC, He S, Bates RC, Camidge DR, Morris SW, El-Hariry I, Proia DA: Targeted inhibition of the 
molecular chaperone Hsp90 overcomes ALK inhibitor resistance in nonsmall cell lung cancer. Cancer Discov 2013, 3:430-443.

101. Ono N, Yamazaki T, Tsukaguchi T, Fujii T, Sakata K, Suda A, Tsukuda T, Mio T, Ishii N, Kondoh O, Aoki Y: Enhanced antitumor activity of erlotinib in combination with the $\mathrm{Hsp} 90$ inhibitor CH5164840 against non-small-cell lung cancer. Cancer Sci 2013, 104:1346-1352.

102. Gallerne C, Prola A, Lemaire C: Hsp90 inhibition by PU-H71 induces apoptosis through endoplasmic reticulum stress and mitochondrial pathway in cancer cells and overcomes the resistance conferred by Bcl-2. Biochim Biophys Acta 1833, 2013:1356-1366.

103. Beere HM, Wolf BB, Cain K, Mosser DD, Mahboubi A, Kuwana T, Tailor P, Morimoto Rl, Cohen GM, Green DR: Heat-shock protein 70 inhibits apoptosis by preventing recruitment of procaspase- 9 to the Apaf-1 apoptosome. Nat Cell Biol 2000, 2:469-475.

104. Saleh A, Srinivasula SM, Balkir L, Robbins PD, Alnemri ES: Negative regulation of the Apaf-1 apoptosome by Hsp70. Nat Cell Biol 2000, 2:476-483.

105. Grem JL, Morrison G, Guo X-D, Agnew E, Takimoto CH, Thomas R, Szabo E, Grochow L, Grollman F, Hamilton JM, Neckers L, Wilson RH: Phase I and pharmacologic study of 17-(allylamino)-17-demethoxygeldanamycin in adult patients with solid tumors. J Clin Oncol 2005, 23:1885-1893.

106. Whetstone $H$, Lingwood C: 3 'Sulfogalactolipid binding specifically inhibits Hsp70 ATPase activity in vitro. Biochemistry 2003, 42:1611-1617.

107. Rérole A-L, Gobbo J, De Thonel A, Schmitt E, Pais de Barros JP, Hammann A, Lanneau D, Fourmaux E, Deminov O, Micheau O, Lagrost L, Colas P, Kroemer G, Garrido C: Peptides and aptamers targeting HSP70: a novel approach for anticancer chemotherapy. Cancer Res 2011, 71:484-495.

108. Endo H, Yano M, Okumura Y, Kido H: Ibuprofen enhances the anticancer activity of cisplatin in lung cancer cells by inhibiting the heat shock protein 70. Cell Death Dis 2014, 5:e1027.

109. Sterrenberg JN, Blatch GL, Edkins AL: Human DNAJ in cancer and stem cells. Cancer Lett 2011, 312:129-142.

110. Rane MJ, Pan Y, Singh S, Powell DW, Wu R, Cummins T, Chen Q, McLeish KR, Klein JB: Heat shock protein 27 controls apoptosis by regulating Akt activation. J Biol Chem 2003, 278:27828-27835.

111. Qi S, Xin Y, Qi Z, Xu Y, Diao Y, Lan L, Luo L, Yin Z: HSP27 phosphorylation modulates TRAIL-induced activation of Src-Akt/ERK signaling through interaction with $\beta$-arrestin2. Cell Signal 2014, 26:594-602.

112. Kim A, Ueda Y, Naka T, Enomoto T: Therapeutic strategies in epithelial ovarian cancer. J Exp Clin Cancer Res 2012, 31:14

113. Hsu H-S, Lin J-H, Huang W-C, Hsu T-W, Su K, Chiou S-H, Tsai Y-T, Hung S-C: Chemoresistance of lung cancer stemlike cells depends on activation of Hsp27. Cancer 2011, 117:1516-1528.

114. McConnell JR, McAlpine SR: Heat shock proteins 27, 40, and 70 as combinational and dual therapeutic cancer targets. Bioorg Med Chem Lett 2013, 23:1923-1928.

115. Prestwich GD: Evaluating drug efficacy and toxicology in three dimensions: using synthetic extracellular matrices in drug discovery. Acc Chem Res 2008, 41:139-148.

116. Cukierman E, Pankov R, Stevens DR, Yamada KM: Taking cell-matrix adhesions to the third dimension. Science 2001, 294:1708-1712.

117. Bokhari M, Carnachan RJ, Cameron NR, Przyborski SA: Culture of HepG2 liver cells on three dimensional polystyrene scaffolds enhances cell structure and function during toxicological challenge. J Anat 2007, 211:567-576.

118. Hall HG, Farson DA, Bissell MJ: Lumen formation by epithelial cell lines in response to collagen overlay: a morphogenetic model in culture. Proc Natl Acad Sci U S A 1982, 79:4672-4676.

119. Do Amaral JB, Urabayashi MS, Machado-Santelli GM: Cell death and lumen formation in spheroids of MCF-7 cells. Cell Biol Int 2010, 34:267-274.

120. Do Amaral JB, Rezende-Teixeira P, Freitas VM, Machado-Santelli GM: MCF-7 cells as a three-dimensional model for the study of human breast cancer. Tissue Eng Part C Methods 2011, 17:1097-1107.

121. Page H, Flood P, Reynaud EG: Three-dimensional tissue cultures: current trends and beyond. Cell Tissue Res 2013, 352:123-131.

122. Spencer VA, Xu R, Bissell MJ: Gene expression in the third dimension: the ECM-nucleus connection. J Mammary Gland Biol Neoplasia 2010, 15:65-71.

123. Luca AC, Mersch S, Deenen R, Schmidt S, Messner I, Schäfer K-L, Baldus SE, Huckenbeck W, Piekorz RP, Knoefel WT, Krieg A, Stoecklein NH: Impact of the $3 \mathrm{D}$ microenvironment on phenotype, gene expression, and EGFR inhibition of colorectal cancer cell lines. PLoS One 2013, 8:e59689.
124. Santini MT, Rainaldi G, Indovina PL: Apoptosis, cell adhesion and the extracellular matrix in the three-dimensional growth of multicellular tumor spheroids. Crit Rev Oncol Hematol 2000, 36:75-87.

125. Waleh NS, Gallo J, Grant TD, Murphy BJ, Kramer RH, Sutherland RM: Selective down-regulation of integrin receptors in spheroids of squamous cell carcinoma. Cancer Res 1994, 54:838-843.

126. Hauptmann S, Denkert C, Löhrke H, Tietze L, Ott S, Klosterhalfen B, Mittermayer C: Integrin expression on colorectal tumor cells growing as monolayers, as multicellular tumor spheroids, or in nude mice. Int $J$ Cancer 1995, 61:819-825.

127. Friedrich J, Eder W, Castaneda J, Doss M, Huber E, Ebner R, Kunz-Schughart $L A$ : A reliable tool to determine cell viability in complex 3-d culture: the acid phosphatase assay. J Biomol Screen 2007, 12:925-937.

128. Hirschhaeuser F, Menne H, Dittfeld C, West J, Mueller-Klieser W, KunzSchughart LA: Multicellular tumor spheroids: an underestimated tool is catching up again. J Biotechnol 2010, 148:3-15.

129. Fourré N, Millot J-M, Garnotel R, Jeannesson P: In situ analysis of doxorubicin uptake and cytotoxicity in a 3D culture model of human HT-1080 fibrosarcoma cells. Anticancer Res 2006, 26:4623-4626.

130. Yip D, Cho CH: A multicellular 3D heterospheroid model of liver tumor and stromal cells in collagen gel for anti-cancer drug testing. Biochem Biophys Res Commun 2013, 433:327-332.

131. Millerot-Serrurot E, Guilbert M, Fourré N, Witkowski W, Said G, Van Gulick L, Terryn C, Zahm J-M, Garnotel R, Jeannesson P: 3D collagen type I matrix inhibits the antimigratory effect of doxorubicin. Cancer Cell Int 2010, 10:26.

132. Godugu C, Patel AR, Desai U, Andey T, Sams A, Singh M: AlgiMatrix ${ }^{\mathrm{TM}}$ based 3D cell culture system as an in-vitro tumor model for anticancer studies. PLoS One 2013, 8:e53708.

133. Damiano JS, Cress AE, Hazlehurst LA, Shtil AA, Dalton WS: Cell adhesion mediated drug resistance (CAM-DR): role of integrins and resistance to apoptosis in human myeloma cell lines. Blood 1999, 93:1658-1667.

134. Sanz-Rodríguez F, Teixidó J: VLA-4-dependent myeloma cell adhesion. Leuk Lymphoma 2001, 41:239-245.

135. Weaver VM, Lelièvre S, Lakins JN, Chrenek MA, Jones JCR, Giancotti F, Werb Z, Bissell MJ: Beta4 Integrin-dependent formation of polarized threedimensional architecture confers resistance to apoptosis in normal and malignant mammary epithelium. Cancer Cell 2002, 2:205-216.

136. Schmidmaier R, Baumann P: ANTI-ADHESION evolves to a promising therapeutic concept in oncology. Curr Med Chem 2008, 15:978-990.

137. Westhoff M-A, Fulda S: Adhesion-mediated apoptosis resistance in cancer. Drug Resist Updat 2009, 12:127-136.

138. Longati P, Jia X, Eimer J, Wagman A, Witt M-R, Rehnmark S, Verbeke C, Toftgård R, Löhr M, Heuchel RL: 3D pancreatic carcinoma spheroids induce a matrix-rich, chemoresistant phenotype offering a better model for drug testing. BMC Cancer 2013, 13:95.

139. Loessner D, Stok KS, Lutolf MP, Hutmacher DW, Clements JA, Rizzi SC: Bioengineered 3D platform to explore cell-ECM interactions and drug resistance of epithelial ovarian cancer cells. Biomaterials 2010, 31:8494-8506.

140. Dong Y, Stephens C, Walpole C, Swedberg JE, Boyle GM, Parsons PG, McGuckin MA, Harris JM, Clements JA: Paclitaxel resistance and multicellular spheroid formation are induced by kallikrein-related peptidase 4 in serous ovarian cancer cells in an ascites mimicking microenvironment. PLoS One 2013, 8:e57056.

141. Chen J, Wang J, Chen D, Yang J, Yang C, Zhang Y, Zhang H, Dou J: Evaluation of characteristics of CD44 +CD117+ ovarian cancer stem cells in three dimensional basement membrane extract scaffold versus two dimensional monocultures. BMC Cell Biol 2013, 14:7.

142. Yang T-M, Barbone D, Fennell DA, Broaddus VC: BCl-2 family proteins contribute to apoptotic resistance in lung cancer multicellular spheroids. Am J Respir Cell Mol Biol 2009, 41:14-23.

143. Lee SY, Jeong E, Jeon HM, Kim CH, Kang HS: Implication of necrosis-linked p53 aggregation in acquired apoptotic resistance to 5-FU in MCF-7 multicellular tumour spheroids. Oncol Rep 2010, 24:73-79.

144. Nirmalanandhan VS, Duren A, Hendricks P, Vielhauer G, Sittampalam GS: Activity of anticancer agents in a three-dimensional cell culture model. Assay Drug Dev Technol 2010, 8:581-590.

145. Neuzil J, Stantic M, Zobalova R, Chladova J, Wang X, Prochazka L, Dong L, Andera L, Ralph SJ: Tumour-initiating cells vs. cancer "stem" cells and CD133: what's in the name? Biochem Biophys Res Commun 2007, 355:855-859. 
146. Dean M, Fojo T, Bates S: Tumour stem cells and drug resistance. Nat Rev Cancer 2005, 5:275-284.

147. Visvader JE, Lindeman GJ: Cancer stem cells in solid tumours: accumulating evidence and unresolved questions. Nat Rev Cancer 2008, 8:755-768.

148. Takaishi S, Okumura T, Tu S, Wang SSW, Shibata W, Vigneshwaran R, Gordon SAK, Shimada Y, Wang TC: Identification of gastric cancer stem cells using the cell surface marker CD44. Stem Cells 2009, 27:1006-1020.

149. Tirino V, Camerlingo R, Franco R, Malanga D, La Rocca A, Viglietto G, Rocco G, Pirozzi G: The role of CD133 in the identification and characterisation of tumour-initiating cells in non-small-cell lung cancer. Eur J Cardiothorac Surg 2009, 36:446-453.

150. Awad O, Yustein JT, Shah P, Gul N, Katuri V, Neill AO, Kong Y, Brown ML, Toretsky JA, Loeb DM, O'Neill A: High ALDH activity identifies chemotherapy-resistant Ewing's sarcoma stem cells that retain sensitivity to EWS-FLI1 inhibition. PLoS One 2010, 5:e13943.

151. Moserle L, Indraccolo S, Ghisi M, Frasson C, Fortunato E, Canevari S, Miotti S, Tosello V, Zamarchi R, Corradin A, Minuzzo S, Rossi E, Basso G, Amadori A: The side population of ovarian cancer cells is a primary target of IFNalpha antitumor effects. Cancer Res 2008, 68:5658-5668.

152. Rybak AP, He L, Kapoor A, Cutz J-C, Tang D: Characterization of spherepropagating cells with stem-like properties from DU145 prostate cancer cells. Biochim Biophys Acta 1813, 2011:683-694.

153. Pastrana E, Silva-Vargas V, Doetsch F: Eyes wide open: a critical review of sphere-formation as an assay for stem cells. Cell Stem Cell 2011, 8:486-498.

154. Marhaba R, Zöller M: CD44 in cancer progression: adhesion, migration and growth regulation. $J$ Mol Histol 2004, 35:211-231.

155. Prince ME, Sivanandan R, Kaczorowski A, Wolf GT, Kaplan MJ, Dalerba P, Weissman IL, Clarke MF, Ailles LE: Identification of a subpopulation of cells with cancer stem cell properties in head and neck squamous cell carcinoma. Proc Natl Acad Sci U S A 2007, 104:973-978.

156. Marchitti SA, Brocker C, Stagos D, Vasiliou V: Non-P450 aldehyde oxidizing enzymes: the aldehyde dehydrogenase superfamily. Expert Opin Drug Metab Toxicol 2008, 4:697-720.

157. Magni M, Shammah S, Schiró R, Mellado W, Dalla-Favera R, Gianni AM: Induction of cyclophosphamide-resistance by aldehyde-dehydrogenase gene transfer. Blood 1996, 87:1097-1103.

158. Sládek NE, Kollander R, Sreerama L, Kiang DT: Cellular levels of aldehyde dehydrogenases (ALDH1A1 and ALDH3A1) as predictors of therapeutic responses to cyclophosphamide-based chemotherapy of breast cancer: a retrospective study. Rational individualization of oxazaphosphorinebased cancer chemotherapeutic regimens. Cancer Chemother Pharmacol 2002, 49:309-321.

159. Cheung AMS, Wan TSK, Leung JCK, Chan LYY, Huang H, Kwong YL, Liang $R$, Leung AYH: Aldehyde dehydrogenase activity in leukemic blasts defines a subgroup of acute myeloid leukemia with adverse prognosis and superior NOD/SCID engrafting potential. Leukemia 2007, 21:1423-1430.

160. Ginestier C, Hur MH, Charafe-Jauffret E, Monville F, Dutcher J, Brown M, Jacquemier J, Viens P, Kleer CG, Liu S, Schott A, Hayes D, Birnbaum D, Wicha MS, Dontu G: ALDH1 is a marker of normal and malignant human mammary stem cells and a predictor of poor clinical outcome. Cell Stem Cell 2007, 1:555-567

161. Marcato P, Dean CA, Giacomantonio CA, Lee PWK: Aldehyde dehydrogenase: Its role as a cancer stem cell marker comes down to the specific isoform. Cell Cycle 2011, 10:1378-1384.

162. Ionta M, Rosa MCC, Almeida RBB, Freitas VMM, Rezende-Teixeira P, Machado-Santelli GMM: Retinoic acid and CAMP inhibit rat hepatocellular carcinoma cell proliferation and enhance cell differentiation. Braz J Med Biol Res 2012, 45:721-729.

163. Goodell MA, Brose K, Paradis G, Conner AS, Mulligan RC: Isolation and functional properties of murine hematopoietic stem cells that are replicating in vivo. J Exp Med 1996, 183:1797-1806.

164. Tirino V, Desiderio V, Paino F, De Rosa A, Papaccio F, La Noce M, Laino L, De Francesco F, Papaccio G: Cancer stem cells in solid tumors: an overview and new approaches for their isolation and characterization. FASEB J 2013, 27:13-24.

165. Lee H, Park S, Kim JB, Kim J, Kim H: Entrapped doxorubicin nanoparticles for the treatment of metastatic anoikis-resistant cancer cells. Cancer Lett 2013, 332:110-119.
166. Reynolds BA, Weiss S: Generation of neurons and astrocytes from isolated cells of the adult mammalian central nervous system. Science 1992, 255:1707-1710.

167. Alamgeer M, Peacock CD, Matsui W, Ganju V, Watkins DN: Cancer stem cells in lung cancer: evidence and controversies. Respirology 2013, 18:757-764.

doi:10.1186/1756-9966-33-37

Cite this article as: Niero et al:: The multiple facets of drug resistance: one history, different approaches. Journal of Experimental \& Clinical Cancer Research 2014 33:37.

\section{Submit your next manuscript to BioMed Central and take full advantage of:}

- Convenient online submission

- Thorough peer review

- No space constraints or color figure charges

- Immediate publication on acceptance

- Inclusion in PubMed, CAS, Scopus and Google Scholar

- Research which is freely available for redistribution 